\title{
Toward a Critical Multilingualism in Canadian Classrooms: Making Local Inroads into a Cosmopolitan Identity
}

\author{
Martin Guardado
}

Drawing on recent work on cosmopolitanism, global citizenship, and critical applied linguistics, this article examines the concept of cosmopolitanism as a viable goal in education in Canada. Particular attention is paid to the inclusion of global citizenship objectives in K-12 language programs in general and in heritage language (HL) curricula in particular. I make a case for consideration of the concept of cosmopolitanism as a key guiding principle at diverse levels of education in formal, non-formal, and informal settings. I argue that in the Canadian context, multilingual education could play a more prominent role in educational agendas as it has the potential to promote cosmopolitan ideals. I conclude that in the framework of official bilingualism and multiculturalism, cosmopolitanism can fruitfully add to discussions about the role of education in the emergence of a Canadian identity.

Puisant dans les travaux récents sur le cosmopolitisme, la citoyenneté mondiale et la linguistique appliquée, cet article examine le concept du cosmopolitisme comme objectif viable en éducation au Canada. On porte une attention toute particulière à l'inclusion des objectifs de citoyenneté mondiale dans les programmes de langue K-12, notamment dans les programmes de langues ancestrales. Je prône la considération du concept de cosmopolitisme comme principe directeur clé à divers niveaux d'éducation et dans des milieux formels, non-formels et informels. Je fais valoir l'idée que dans le contexte canadien, l'éducation plurilingue pourrait jouer un rôle plus important en enseignement puisqu'il elle peut promouvoir des idéaux cosmopolites. En conclusion, j'affirme qu'au sein du cadre de bilinguisme et de multiculturalisme officiels, le cosmopolitisme peut enrichir les discussions sur le rôle de l'éducation dans l'émergence de l'identité canadienne.

All over the world there is currently a growing trend in higher education toward internationalization and the promotion of global citizenship. This trend is not limited to higher education, however, as many public and private school systems in disparate geographical settings are beginning to incorporate related objectives in their curricula. In Canada, for example, there is evidence of the promotion of global citizenship at all levels of education, as university presidents, school board and ministry of education officials, and other people in positions of influence endeavor to offer world-class education. In this fast-paced and frantically evolving context, critics argue that 
these efforts are often motivated by economic goals as a result of prevailing ideologies surrounding globalization: a phenomenon that has been said to be controlled by market economics (Wodak et al., 1999). In fact, a growing debate in critical education in academic circles today stems from an increasing trend toward the commodification of education at all levels (Giroux \& Myrsiades, 2001; Lewis, 2008; Naidoo \& Jamieson, 2005). Objectives related to human interconnectedness and the recognition and cultivation of global cultural diversity are less frequently emphasized. Moreover, although it is indisputable that language plays a key role in such processes, its significance is not always recognized.

The purpose of this article is to examine the concept of cosmopolitanism as a viable ideological goal in education in Canada. I begin with a brief historical overview and discussion of cosmopolitanism and related terms. I then link current characterizations of cosmopolitanism to language in general and to heritage language development (HLD) in particular. I argue for a strong interrelationship between HLD and cosmopolitan ideals, suggesting that this link should be considered in educational policy, curriculum development, and pedagogy, at all levels, but particularly in heritage language (HL) and other language programs. I tie this discussion to Canadian educational policy and curriculum documents. I conclude with a call to emphasize this key dimension in discussions about education and the role of cosmopolitanism in the emergence of a Canadian identity in the context of official bilingualism and multiculturalism policies.

\section{Transnationalism, Cosmopolitanism, and Global Citizenship}

Although closely related to each other, and sometimes used interchangeably, the constructs of transnationalism, cosmopolitanism, and global citizenship are not synonymous concepts. Transnationalism refers to communities comprising individuals settled in diverse national societies. Some of the characteristics of these groups and individuals may include the embrace of common religious, territorial, linguistic and other interests across national boundaries (Faist, 1998). The concept of cosmopolitanism has been employed for over two millennia, having been first used by the ancient Greeks. It is said that Diogenes, a 4th-century BC philosopher, famously declared, "I'm a citizen of the world." Etymologically, the term cosmopolitanism comes from kosmopolitês, which translates as "a citizen of the world" (Roudometof, 2005). Cosmopolitanism as a concept, then, was first developed by the Greek school of philosophers known as the Cynics, co-founded by Diogenes, to refer to a universal love for humankind regardless of origin or political affiliation. The concept was later redefined and expanded by Greek Stoic philosophers in the 3rd century BC, who emphasized ethics and added the principle of living in harmony with the universe. Almost 2,000 years later, Kant (1983) proposed a federation of nations and perpetual peace, ideas that expounded cosmopolitan ideals and 
harmony among diverse peoples. The distinction between the first two terms, then, is that transnationalism describes the experiences of individuals across borders and cosmopolitanism refers to the attitudes and identities (the ideologies) that these and other people may possess and subscribe to. These concepts are often collocated with internationalization and globalization. Essentially, internationalization is a form of reaching out to the world intentionally and purposively, possibly in a way that is akin to Beck's (2000) idea of "globalization from within," a concept to which I return below. Globalization, on the other hand, refers to global forces affecting our lives in a topdown manner, whether we agree or disagree with them. In this sense, Kofi Annan, former Secretary-General of the United Nations, has frequently been quoted as saying, "arguing against globalization is like arguing against the laws of gravity" (Lule, 2012; Maurer, 2011).

That the term kosmopolitês has often been translated as "citizen of the world" bears witness to the fact that the idea of global citizenship has also been around since ancient times. The term has gained considerable currency in recent decades as a result of unrelenting globalization processes. In July 2008, then Senator Barack Obama stated in his speech "A World That Stands as One" (delivered in Tiergarten, Berlin) that "the burdens of global citizenship continue to bind us together ... Partnership and cooperation among nations is not a choice; it is the one way, the only way, to protect our common security and advance our common humanity." Although Obama was speaking from a particular perspective, a political agenda that draws on the discourses of terrorism and "homeland security," the essence of his arguments still holds. Specifically, it provides us with an example of the diversity of locations where the discourses of global citizenship can be found today, discourses that at times call for a federation of nations in the style of Kant.

Today, there are myriad definitions of cosmopolitanism, or cosmopolitanisms, departing from economic, moral, and cultural perspectives. A review of contemporary characterizations of cosmopolitanism across some of these areas yields an integrated appreciation of the concept. This synthesized view reveals that it is understood as a mobility of people, objects, images, cultures, and ideas (Germann Molz, 2005) across diverse spaces. It also suggests a relationship between the local, the national, and the global (Starkey, 2007). Thus it connotes a "global sense of place" (Massey, 1994, p. 12) and feeling "at home in the world" (Brennan, 1997, book title), which emphasizes a repositioning of personal and collective cultural identities. A cosmopolitan outlook fosters the recognition of others (Delanty, 2006) by assuming a "stance of openness towards divergent cultural experiences" (Hannerz, 1990, p. 239).

Many prominent contemporary thinkers have engaged with cosmopolitanism and related concepts (Appadurai, 2000; Appiah, 2006; Beck, 2002a; Cheah \& Robbins, 1998; Mignolo, 2000, 2006, 2010; Nussbaum, 2008; Parekh, 2003; Pollock et al., 2002). However, the focus of this article allows me to al- 
locate space for only a brief mention of some of their perspectives without fully articulating the theories of anyone in particular. Beck's $(2000,2002 \mathrm{a}$, $2002 b, 2002 c$, 2006) work in this area, for example, is multifaceted and widely cited. To him, writing from a politico-economic perspective, a central feature of cosmopolitans is the ability to deal creatively with tensions between and within cultures. He argues that traditional dualities (local-global, nationalinternational) no longer make sense because these boundaries have now been blurred. The polygamy of place (Beck, 2000, 2006) facilitated by globalization and communication technology leads to the merging of multiple loyalties and identities in people's lives (Beck \& Sznaider, 2006). Furthermore, Beck (2000b) argues for a distinction between cosmopolitanism and cosmopolitanization; for him, cosmopolitanism is an abstract, ancient ideal, whereas cosmopolitanization is a framework for empirically investigating "globalization from within" (p. 26).

Appiah (2006), a somewhat reluctant but self-proclaimed rooted cosmopolitan, writes from the discipline of ethics. Although Appiah's book-length account of cosmopolitanism is obviously much more nuanced and convincing than any simplistic outline I could offer, his version of cosmopolitanism can be summed up in two broad principles: responsibility for strangers and universality plus difference. Often drawing on his own childhood experiences in Ghana, he argues that cosmopolitanism presupposes the recognition that we have an ethical responsibility to every human, regardless of his or her location. Because everyone matters, we have obligations to strangers, and this requires taking their interests seriously. Being careful to distance himself from moral relativism, Appiah proposes the principle of universality plus difference, pointing out that his cosmopolitanism is not the same as universalism. His notion of rooted cosmopolitanism emphasizes the need to engage with the experiences and ideas of others across identity borders, while maintaining one's local affiliations. Appiah admits, however, that the moral principles contained in his cosmopolitanism are highly idealistic and possibly hard to comprehend or achieve.

Mignolo (2000) defines globalization as "a set of designs to manage the world" from above and cosmopolitanism as "a set of projects toward planetary conviviality" (p. 721). He explains that the initial steps of today's globalization were taken in the 16th century with the drawing of the first empirically informed world map. Based on the analysis of several "cosmopolitan projects" from the 16th to the early 20th centuries, Mignolo aptly argues for a critical and dialogic cosmopolitanism, which he sees as essential in the current globalizing world. He describes critical cosmopolitanism as "globalization from below," echoing Beck's "globalization from within." The main distinctions between the two may well be of focus and scale. Beck's focus is on politics and economics and Mignolo's is on critical ethics and social justice. Whereas Beck's "globalization from within" is meant to describe 
cosmopolitanization as a process of internalizing globalization by the nationstate, Mignolo's "globalization from below" attempts to open spaces for "silenced and marginalized voices" to be heard as they attempt to bring themselves into cosmopolitan conversations. To open such spaces, Mignolo proposes the concept of border thinking. This refers to envisioning a transformation of hegemonic powers from the point of view of marginalized subject positions. He also proposes the concept of diversality - diversity as a universal project-which contains border thinking as an essential feature. Essentially, Mignolo argues that it is the task of critical cosmopolitanism to acknowledge the injustices of past and present global designs, to have human rights at its core, and to look toward the future. Cosmopolitanism, he continues, is not a new form of cultural relativism, but should be ethically understood as an idea being projected and imagined from the perspective of the non-elite masses. To sum up, Mignolo's cosmopolitanism presupposes a critical engagement with universal diversity and human rights as well as critical conversations and thinking that privilege the perspectives of the marginalized other.

Cosmopolitanism continues to be a protean term (Mehta, 2000). It is a highly elusive concept with no obviously consistent or unified definition. Its conflation with internationalism, transnationalism, global citizenship, and even globalization further contributes to its slippery nature. Whereas some scholars propose internationalism as a more manageable concept, others argue that internationalism is only a component of cosmopolitanism. Global citizenship is most often used as a substitute term for cosmopolitanism, but this concept too is often rejected given its untenable implication of a global state. Parekh (2003), for example, makes a strong case for the use of globally oriented citizen in its place. This term, he posits, does not imply the formation of a global state, yet it retains some of the most desirable elements of cosmopolitanism, namely, the recognition of and interest in all humankind. Parekh emphatically rejects both global citizenship and cosmopolitanism, and yet the globally oriented citizenship that he proposes is arguably no different from some contemporary definitions of cosmopolitanism, notably that of Appiah's (2006) rooted cosmopolitanism. Therefore, discussions of cosmopolitanism, transnationalism, global citizenship, and internationalization are always affected by how one defines such concepts.

At the risk of being conceptually promiscuous, but I hope exonerated given Beck's idea of place polygamy, I operationalize my definition of cosmopolitanism by drawing on a range of available understandings, particularly those that recur in the literature as described above. Thus cosmopolitanism is to be understood here as a symbiotic blend of cultures where two or more are dominant. In other words, it nurtures multiple belonging through the possession of adaptable dispositions. Cosmopolitanism entails valuing and recognizing diverse cultures and identities, irrespective of whether they are local or distant. It focuses on the moral responsibilities 
that we have toward all human beings regardless of nationality, religion, political affiliation, color, language, geographical location, or social status as an ethical obligation and as an act of promoting and protecting human rights. Despite an abundance of cosmopolitanisms, one element that they share is that all humans should see themselves as members of one community, one group, and that this community should be nurtured and protected. Furthermore, I emphasize my leaning toward Appiah's (2006) rooted cosmopolitanism, which deviates from conceptualizations that assume that cosmopolitans are "voluntary exiles" (Nussbaum, 2008; Parekh, 2003) with no local community allegiances. Despite some perspectives that argue for the contrary, cosmopolitanism also allows people to draw on the country of origin as a source of identity. Thus in our present conceptualization of cosmopolitanism, a cosmopolitan disposition does not preclude narrower identifications based on local or national loyalties (Appiah; Kastoryano, 2000; Pichler, 2009; Pollini, 2005; Robertson, 1992).

As discussed above, the terms global citizenship, globalization, transnationalism, internationalization, and cosmopolitanism can often be sources of much conceptual confusion. Although they can be highly complex constructs that are understood in varied ways in diverse disciplines and contexts, I attempt to provide a somewhat simplified distinction among them. Cosmopolitanism assumes an acknowledgment of the human, cultural, and moral features of globalization and internationalization. Therefore, I see an important distinction between global citizenship and cosmopolitanism for two main reasons. Global citizenship seems to be a close ally of globalization, a term with highly criticized undertones of colonialization and corporatization. In addition, as Parekh (2003) has argued, global citizenship implies the existence of a global state, which is unrealistic and perhaps undesirable, especially because it would probably be oppressive and unequal

Today, the concept of cosmopolitanism is arguably less well understood than global citizenship, and as a result, it may be excoriated and dismissed on a variety of grounds. For example, considerable conceptual work will be required to attain a more overt consensus of how cosmopolitanism should be comprehended or even integrated into teaching practice. In this regard, a significant pedagogical hurdle is posed by its abstract and idealistic nature. Cosmopolitanism may also be regarded, excusably, as exclusionary for its historical association with the educated urban middle class. As such, it may be argued, it provides urban elites with a further attribute to index and affirm their distinction. These and many other limitations should not be ignored, but critically probed and discussed at various levels. Thus cosmopolitanism should not be seen as a panacea for the shortcomings of the Canadian education system, but rather, when sufficiently operationalized, as a guiding ideal and reflective tool for Canadians affected by and interested in education. 
Given the ambiguity of cosmopolitanism, for the sake of conceptual conciseness, in this article I sometimes refer to global citizenship as a close equivalent to cosmopolitanism: a conceptual stepping stone. Because processes of globalization tend to create favorable conditions for hybrid identities to evolve (Hall \& Du Gay, 1996), I see the concept of global citizenship as an ideological mid-point between parochial and cosmopolitan identities. Although Kant's ambitious proposition of permanent peace among nations and peoples continues to elude humankind, as it perpetually has, the time may be ripe for educational scholarship and policy in Canada to harvest elements of over two millennia of cosmopolitanism propositions and projects. Thus the sections that follow begin this conversation in an attempt to address such an argument.

\section{Cosmopolitanism and Education}

\section{Higher Education}

Many universities across Canada are pursuing goals of internationalization, mainly due to increases in the international student population, and are promoting global citizenship among all university members. This emphasis in the academy is linked to the notions of cosmopolitanism discussed above. The University of Alberta, the University of British Columbia, and the University of Toronto are all promoting global citizenship goals to varying degrees through rhetoric in their vision and academic plans, as well as in concrete initiatives "on the ground." For example, the University of Alberta's vision, as part of President Indira Samarasekera's Dare to Deliver (2007) university plan, states that the university attempts to benefit an Alberta, the citizens of which "move globally, and its industry, which engage[s] globally." The Department of Educational Policy Studies in the Faculty of Education at this university houses the Global Education Network. Inspired by the 2004 conference "Educating for Human Rights and Global Citizenship," one of the Global Education Network's main goals is to engage in local-global efforts that address social justice. The key players in this initiative are professors Ali Abdi and Lynette Shultz, who are also currently spearheading the Global Citizenship Curriculum Development (GCCD) project, which attempts to establish their university as an institution that is "recognized internationally as a leader in the field of global citizenship education." As part of this initiative, the team is working to incorporate global citizenship content into existing university curricula, develop an undergraduate course on global citizenship, and develop a Global Citizenship Certificate Program.

The University of British Columbia (2009) states in its institutional vision that it fosters "global citizenship, advances a civil and sustainable society, and supports outstanding research to serve the people of British Columbia, Canada and the world." It further asserts its commitment to these goals in its 
latest strategic plan Place and Promise: The UBC Plan, where commitments, goals and actions of global citizenship, social sustainability, Aboriginal education, community engagement, and other promises are carefully articulated.

Interestingly, global citizenship goals are absent from the University of Toronto's (2008) discussion paper entitled Towards 2030: Planning for a Third Century of Excellence at the University of Toronto. Global citizenship is mentioned only once in passing in the Synthesis Report of the above document: "the University benefits greatly from the multicultural milieu of the Toronto region, and the ethno-cultural diversity of our student body. These facets of the University help our students to become global citizens, but are not a substitute for travel and study abroad" (p.43). And yet the University of Toronto has one of the most innovative and practically oriented global citizenship initiatives focusing on K-12 education. With funding from the Canadian International Development Agency's (CIDA) Global Classroom Initiative, the Comparative, International and Development Education Centre (CIDEC) at the University of Toronto is working on a number of projects with a global outlook. One of their projects is Educating for Global Citizenship in a Changing World, a free downloadable book for practicing teachers and teacher educators in school settings in the Toronto area.

\section{Cosmopolitanism and Language}

Scholars have recently made some connections between cosmopolitanism and language that are worth noting. Guilherme (2007) examined the potential of English as a global language for minorities to function as cosmopolitan citizens without suffering cultural loss. She posits that as members of local and global communities, language-learners have rights and obligations, and calls for a critical language education that makes language-learners aware of their rights and obligations as members of local and global communities. To give a more concrete example, Dora the Explorer, Nickelodeon's foray into the preschool television viewership, has been found to connect bilingualism and cosmopolitanism. Popp (2006) claims that parents, mainly non-Hispanic, see Dora's bilingualism as a sign of her cosmopolitanism. By watching the program, they believe that their children accumulate cultural capital and obtain prestige. Such capital, he contends, is easily converted into cosmopolitanism. Therefore, he concludes that the series helps children also become cosmopolitan.

In a recent article (Guardado, 2010), I presented findings from an ethnographic study of Hispanic-Canadians living in metropolitan Vancouver. The article focused on the families' views on the relationship between their children's maintenance of Spanish and their identity. The analysis showed that the participating families' constructions of HLD echoed those found in current discourses of cosmopolitanism. For these families, HLD was part of their view of Spanish as key to the development and maintenance of syncretic identities, to membership in a pluralistic society, and to a cosmopolitan out- 
look that valued global citizenry and a broader vision of the world. For these families, HLD meant more than just preserving an elusive past; it was part of their goal of raising their children as cosmopolitans who could make meaningful connections between the local and the global. To them, this process would enable their children to see the world through multiple lenses and cultural systems. The families spoke explicitly about their desire to foster global citizenship in their children through their heritage language.

\section{Cosmopolitanism in Canadian K-12 Curricula}

With the goal of understanding this issue from the perspective of the public school system in Canada, I am currently conducting an examination of Canadian educational policy and curricular documents. This work consists of a preliminary content analysis of the K-12 curriculum documents for social studies and language programs in 10 provinces and three territories with the goal of identifying if, to what extent, and how these programs promote objectives of internationalization, global citizenship, and cosmopolitanism.

Early findings from the Prairie provinces and Western Canada show that explicit objectives and content related to global citizenship and cosmopolitanism are absent from the British Columbia and Yukon documents. Implicit content related to these concepts is also mostly absent. The Prairie provinces of Saskatchewan, Manitoba, and Alberta, on the other hand, paint a different picture. Not only are these concepts an integral part of the social studies and language programs in K-12 schooling, but global citizenship is a central tenet of the language programs specifically for these three provinces. The language program curricula are based on the Common Curriculum Framework for International Languages, Kindergarten to Grade 12, which is a joint project of the Western Canadian Protocol for Collaboration in Basic Education (2000). The Common Curriculum follows an integrative framework of language-learning that progresses spirally through all grades starting in kindergarten. The four pillars that support the curriculum are applications, language competence, global citizenship, and strategies. Thus although global citizenship is introduced only in grade 3 social studies, it becomes central in language programs starting in kindergarten.

The above summary suggests that current trends in the Canadian public school system are moving toward the promotion of broader world views, at least in some provinces. In addition, there seems to be interest among middle-class Anglo-Canadians toward bilingualism, mainly through their children's enrollment in French immersion programs, but also through bilingual programs in languages such as Mandarin Chinese and perhaps through their own enrollment in foreign-language courses. Recent reports indicate that middle-class immigrant families are also being drawn to French immersion (Dagenais \& Berron, 2001; Guardado, 2008). These tendencies point to growing recognition of the value and desirability of multilingualism in Canada, a 
goal that has recently been stressed by several Canadian scholars (Duff, 2007). Because immigrant Canadians such as the Hispanic families discussed above make direct connections between heritage languages and a broader vision of the world, and considering that language education programs in some provinces also make similar connections and have built related objectives into their curricula, it may be time to emphasize these goals in educational policy and practice. I posit that societal multilingualism may lead to cosmopolitanism in Canada, and that this move will benefit all society. In order for this to occur, I call for a renewed, more ethical version of cosmopolitanism. A frequent criticism of cosmopolitanism is its elitism. Today's cosmopolitanism, however, has "a new cast of characters" (Robbins, 1998, p. 1). These emerge from the increasing movement and interdependence of people across geographical and virtual borders, including nannies, guest workers, and members of various diasporas. I would argue that it is time to think beyond a restricted and elitist cosmopolitanism and to move toward a popular cosmopolitanism, a notion that accounts for the desires, experiences, and forms of capital of all populations.

\section{From Multiculturalism to Cosmopolitanism}

An important aspect emerging from the above analysis relates to multicultural and educational policy. Canada embraced a policy of official multiculturalism in a "bilingual framework" in the early 1970s. However, the Canadian bilingualism framework seems to be fully supported across Canada only if it is French-English bilingualism. This was a good start in the 1960s when both languages (and associated cultures) were made the official languages of the country, resolutely elevating the status of French. This continues to be significant because in several regions, particularly in the Maritimes, French is a minority language that shares various challenges with HLs. Yet four decades and millions of immigrants from diverse nations later, it is time to take the next steps. The implication that official multiculturalism should also be understood as multilingualism at the moment does not seem to be of enough concern to those in positions of influence (e.g., policymakers, schoolteachers). There is a need for a better understanding of how these official policies facilitate school boards' efforts in fostering heritage languages, and how provincial ministries of education, school boards, and school districts across the country interpret Canada's official multiculturalism policies, as well as how they implement, or fail to implement, support programs. Integrating HL programs more assertively in schools and creating more opportunities for minority and majority students to work together on language issues would be an important step. It would be a key move away from a stance that currently privileges the Anglicization and cultural assimilation of Canada's linguistic minorities and toward adopting a position that cham-

pions diversification of thinking and multilingualization of Canada's Anglo 
majority, as well as being a way of promoting a cosmopolitan orientation in all Canada's populations. If this is not a reasonable move for educational policy, then we have to ask ourselves: Is Canada's ideology of multiculturalism a deeply rooted value reflected in educational policy or is it only a "celebratory multiculturalism"?

\section{Cosmopolitanism in Educational Practice}

In education and applied linguistics, cosmopolitanism has been discussed from a number of perspectives. A common thread appears to connect the notion of cosmopolitanism to the current emphasis in academic circles on developing global citizens, particularly in college and university presidents' discourses. More specifically, however, Luke (2004) has called for a major rethinking of the teaching profession as cosmopolitan work. He argues that this reconceptualization requires the "cultural, linguistic, epistemological diversification and, potentially, hybridization of the very educational institutions where we work" (p. 1439). He adds that this would entail the reenvisioning of a new transcultural and cosmopolitan teacher "with critical capacities for dealing with the transnational and the global" (p. 1439). This would also require the ability to converse with educators, researchers, curriculum developers, and educational bureaucrats physically and virtually across regional and global boundaries, especially in relation to the various forms of diversity that now are commonplace. Part of this ideal would require envisioning a world where everyone can speak as equals and "expanding the purview, scope, and gaze of the school curriculum" (Luke, Luke, \& Graham, 2007, p. 12). Luke et al.'s theorizing of critical pedagogy from a cosmopolitanism perspective may be seen as an instantiation of critical cosmopolitanism notions such as that articulated by Mignolo (2000).

\section{Cosmopolitanism and Canadian Identity}

Considering the above discussion, it is therefore crucial to conceptualize the development and maintenance of minority languages (which in some contexts include French) in more progressive and encompassing terms that highlight the positive effects of this process and its role as a bridge to the promotion of societal multilingualism. Because classrooms are the locus for change (MacDonald \& Monkman, 2005), teachers need to promote more decisively supportive and inclusive classroom communities (Brown, 2007). Thus these classrooms need to become sites where languages and cultures, both minority and majority, are valorized and where both linguistic-minority and majority students are given opportunities to engage in critical dialogue, to foster positive multicultural attitudes, and to cultivate their potential for multilingualism (Duff, 2007) as part of the school's official ethos and agenda. In this way, all students may have opportunities to develop cosmopolitan identities and grow up to be citizens who are not only tolerant of difference, 
but who embrace and value difference as a key social and human resource. These cosmopolitan citizens will develop dispositions and stances of openness toward diverse cultural experiences (Hannerz, 1990, as in Mignolo's diversality or Appiah's universality plus difference), construct identities that combine local and broad senses of belonging (Luke et al., 2007), and assume more adaptable perspectives and a stronger commitment to local and global cohesion and ethnolinguistic diversity (Smith, 2007), all of which are arguably desirable assets in the current climate of unprecedented cultural exchange and globalization. Thus a cosmopolitan turn promises to contribute to the educational needs of a rapidly changing global context. As noted above, aspects of this line of thinking are starting to be embraced in Canada by a segment of linguistic-minority and majority families as well as in the education offices of several provinces and universities.

Teachers in North America continue to be mostly monocultural and monolingual (Nieto, 2005; Rodriguez, 2007). Because teaching around and with difference is the most challenging question in education today (Luke, 2004; Luke \& Goldstein, 2006), the above goals are not attainable unless their pursuit is extended to teachers so that they develop interest and skills in additional languages and become more aware of multicultural issues (Nieto, 1999), potentially leading to their own development of a broader vision of the world. Only then, I believe, will the goal of advancing an effective and culturally responsive pedagogy in multicultural and multilingual settings be within reach.

\section{Acknowledgments}

I acknowledge the generous support of the Social Sciences and Humanities Research Council of Canada (SSHRC) for funding part of the research that inspired this article. I also thank the Editor, Dr. Marian Rossiter, and the TESL Canada Journal anonymous reviewers for their helpful suggestions.

\section{The Author}

Martin Guardado is an assistant professor of applied linguistics and the Academic Director of the English Language Program at the University of Alberta. His publications deal with language socialization, heritage language development, language ideologies, English as a second language, and the role of technology in language education.

\section{References}

Appadurai, A. (2000). Spectral housing and urban cleansing: Notes on millennial Mumbai. Public Culture, 12, 627-651.

Appiah, K.A. (2006). Cosmopolitanism: Ethics in a world of strangers. New York: W.W. Norton.

Beck, U. (2000). Living your own life in a runaway world: Individualisation, globalisation and politics. In W. Hutton \& A. Giddens (Eds.), On the edge: Living with global capitalism (pp. 164-174). London: Jonathan Cape.

Beck, U. (2002a). The cosmopolitan perspective: Sociology in the second Age of Modernity. In S. Vertovec \& R. Cohen (Eds.), Conceiving cosmopolitanism: Theory, context, and practice (pp. 61-85). Oxford, UK: Oxford University Press. 
Beck, U. (2002b). The cosmopolitan society and its enemies. Theory, Culture and Society, 19(1-2), $17-44$.

Beck, U. (2002c). The terrorist threat: World risk society revisited. Theory, Culture and Society, 19(4), 39-55.

Beck, U. (2006). Cosmopolitan vision. Cambridge, UK: Polity Press.

Beck, U., \& Sznaider, N. (2006). Unpacking cosmopolitanism for the social sciences: A research agenda. British Journal of Sociology, 57(1), 1-23.

Brennan, T. (1997). At home in the world: Cosmopolitanism now. Cambridge, MA: Harvard University Press.

Brown, S.A. (2007). A critical discourse analysis of identity development and literacy practices: Latino English language learners at home and in the primary classroom. Unpublished doctoral dissertation, University of South Carolina.

Cheah, P., \& Robbins, B. (Eds.). (1998). Cosmopolitics: Thinking and feeling beyond the nation. Minneopolis, MN: University of Minnesota Press.

Dagenais, D., \& Berron, C. (2001). Promoting multilingualism through French immersion and language maintenance in three immigrant families. Language, Culture and Curriculum, 14(2), 142-155.

Delanty, G. (2006). The cosmopolitan imagination: Critical cosmopolitanism and social theory. British Journal of Sociology, 57(1), 25-47.

Duff, P.A. (2007). Multilingualism in Canadian schools: Myths, realities and possibilities. Canadian Journal of Applied Linguistics, 10, 149-163.

Faist, T. (1998). Transnational social spaces out of international migration: Evolution, significance and future prospects. European Journal of Sociology, 39, 213-247.

Germann Molz, J. (2005). Getting a "flexible eye": Round-the-world travel and scales of cosmopolitan citizenship. Citizenship Studies, 9, 517-531.

Giroux, H.A., \& Myrsiades, K. (Eds.). (2001). Beyond the corporate university: Culture and pedagogy in the new millenium. Lanham, MD: Rowman \& Littlefield.

Guardado, M. (2008). Language, identity, and cultural awareness in Spanish-speaking families. Canadian Ethnic Studies, 40(3), 171-181.

Guardado, M. (2010). Heritage language development: Preserving a mythic past or envisioning the future of Canadian identity? Journal of Language, Identity, and Education, 9, 329-346.

Guilherme, M. (2007). English as a global language and education for cosmopolitan citizenship. Language and Intercultural Communication, 7(1), 72-90.

Hall, S., \& Du Gay, P. (Eds.). (1996). Questions of cultural identity. London: Sage.

Hannerz, U. (1990). Cosmopolitans and locals in world culture. In M. Featherstone (Ed.), Global culture: Nationalism, globalization and modernity (pp. 237-252). London: Sage.

Kant, I. (1983). Perpetual peace, and other essays on politics, history, and moral practice (T. Humphrey, Trans.). Indianapolis, IN: Hackett.

Kastoryano, R. (2000). Settlement, transnational communities and citizenship. International Social Science Journal, 52(165), 307-312.

Lewis, M. (2008). Public good or private value: A critique of the commodification of knowledge in higher education-A Canadian perspective. In J.E. Canaan \& W. Shumar (Eds.), Structure and agency in the neoliberal university (pp. 45-66). New York: Routledge.

Luke, A. (2004). Teaching after the market: From commodity to cosmopolitan. Teachers College Record, 106, 1422-1443.

Luke, A., \& Goldstein, T. (2006). Building intercultural capital: A response to Rogers, Marshall, and Tyson. Reading Research Quarterly, 41, 202-224.

Luke, A., Luke, C., \& Graham, P. (2007). Globalization, corporatism, and critical language education. International Multilingual Research Journal, 1, 1-13.

Lule, J. (2012). Globalization and media: Global village of Babel. Plymouth, UK: Rowman \& Littlefield.

TESL CANADA JOURNAL/REVUE TESL DU CANADA 
MacDonald, V., \& Monkman, K. (2005). Setting the context: Historical perspectives on Latino/a education. In P. Pedraza \& M. Rivera (Eds.), Latino education: An agenda for community action research (pp. 47-74). Mahwah, NJ: Erlbaum.

Massey, D. (1994). Space, place, and gender. Minneapolis, MN: University of Minnesota Press.

Maurer, S. (2011). Former British colony: Mauritians in the face of globalisation. Antrocom Online Journal of Anthropology, 7, 235-250.

Mehta, P.B. (2000). Cosmopolitanism and the circle of reason. Political Theory, 28, 619-639.

Mignolo, W.D. (2000). The many faces of cosmo-polis: Border thinking and critical cosmopolitanism. Public Culture, 12, 721-748.

Mignolo, W.D. (2006). Citizenship, knowledge, and the limits of humanity. American Literary History, 18, 312-331.

Mignolo, W.D. (2010). Cosmopolitanism and the de-colonial option. Studies in Philosophy and Education, 29, 111-127.

Naidoo, R., \& Jamieson, I. (2005). Knowledge in the marketplace: The global commodification of teaching and learning in higher education. In P. Ninnes \& M. Hellstén (Eds.), Internationalizing higher education: Critical explorations of pedagogy and policy (pp. 37-52). Dordrecht, Netherlands: Springer.

Nieto, S. (1999). The light in their eyes: Creating multicultural learning communities. New York: Teachers College Press.

Nieto, S. (Ed.). (2005). Why we teach. New York: Teachers College Press.

Nussbaum, M.C. (2008). Toward a globally sensitive patriotism. Daedalus, 137, 78-93.

Parekh, B. (2003). Cosmopolitanism and global citizenship. Review of International Studies, 29, 3-17.

Pichler, F. (2009). “Down-to-earth" cosmopolitanism: Subjective and objective measurements of cosmopolitanism in survey research. Current Sociology, 57, 704-732.

Pollini, G. (2005). Elements of a theory of place attachment and socio-territorial belonging. International Review of Sociology, 15, 497-515.

Pollock, S., Bhabha, H.K., Breckenridge, C.A., \& Chakrabarty, D. (2002). Cosmopolitanisms. In C.A. Breckenridge (Ed.), Cosmopolitanism (pp. 1-14). Durham, NC: Duke University Press.

Popp, R.K. (2006). Mass media and the linguistic marketplace: Media, language, and distinction. Journal of Communication Inquiry, 30(1), 5-20.

Robbins, B. (1998). Introduction part I: Actually existing cosmopolitanism. In P. Cheah \& B. Robbins (Eds.), Cosmopolitics: Thinking and feeling beyond the nation (pp. 1-19). Minneopolis, MN: University of Minnesota Press.

Robertson, R. (1992). Globalization: Social theory and global culture. London: Sage.

Rodriguez, T.L. (2007). Language, culture, and resistance as resource: Case studies of bilingual/bicultural Latino prospective elementary teachers and the crafting of teaching practices. Unpublished doctoral dissertation, University of Wisconsin, Madison.

Roudometof, V. (2005). Transnationalism, cosmopolitanism and glocalization. Current Sociology, 53, 113-135.

Smith, W. (2007). Cosmopolitan citizenship: Virtue, irony and worldliness. European Journal of Social Theory, 10(1), 37-52.

Starkey, H. (2007). Language education, identities and citizenship: Developing cosmopolitan perspectives. Language and Intercultural Communication, 7(1), 56-71.

University of Alberta. (2007). Dare to deliver: University of Alberta academic plan. Available: http://www.president.ualberta.ca/en/ /media/Office\%20of\%20the\%20President/Docu ments/D2D/DaretoDeliver.pdf

University of British Columbia. (2009). Place and promise: The UBC plan. Available: http:/ / strategicplan.ubc.ca/files/2009/11/UBC-PP-Layout-Aug2012.pdf

University of Toronto. (2008). Towards 2030: A third century of excellence at the University of Toronto. Available: http://www.towards2030.utoronto.ca/files/2030_REDUXv7.pdf 
Western Canadian Protocol for Collaboration in Basic Education. (2000). The common curriculum framework for international languages: Kindergarten to grade 12. Available: http://www.wncp.ca/media/44398/wcpinter.pdf

Wodak, R., de Cillia, R., Reisigl, M., \& Liebhart, K. (1999). The discursive construction of national identity (A. Hirsch \& R. Mitten, Trans.). Edinburgh, UK: Edinburgh University Press. 